\title{
Salvadorean Refugees in Honduras
}

\author{
By Sandra Pentland and Denis Racicot
}

Since the very beginning of their saga, when thousands of Salvadoreans fleeing the brutal repression of the Salvadorean military and paramilitary sought refuge in Honduras, the key issue has been one of protection. Both the religious and lay people of the diocese of Santa Rosa were quick to respond and the church played a very important role in assisting and protecting the refugees pouring into its area. Many Honduran peasants living near the border opened their hearts and their homes, sharing the little they had with their Salvadorean brothers and sisters. In stark contrast to the impressive human solidarity of many of the Honduran people, the Honduran military entered into complicity with the Salvadorean military.

In May 1980, the Salvadorean army, along with members of the infamous paramilitary group, ORDEN, carried out a vast operation in Chalatenango, in one of the northern provinces of El Salvador. On May 14, more than 4,000 Salvadorean peasants (mainly women, children and elderly people) tried to flee across the Sumpul River into Honduras. Met by the Honduran army, they were forced to return to the Salvadorean side of the river where they were mercilessly hunted down by the Salvadorean army. In the ensuing massacre, more than 600 Salvadoreans were killed. (Only three days before, the heads of the Salvadorean and Honduran armies had met in El Poy, a town on the border of the two countries.)

This joint operation with the Salvadorean military was the first concrete manifestation of the attitude of the Honduran authorities towards the refugees. The authorities consider the refugees subversive because they fled from government and government-linked paramilitary forces. (Given that these people saw family members brutally assassinated, and their homes, crops and personal belongings destroyed by government forces, it is not surprising that they have little regard for the Salvadorean government.) This overt hostility on the part of the Honduran authorities has led to very serious security problems for the refugees over the years.

Throughout 1980, Salvadoreans continued to pour into Honduras. At first, the
Honduran government refused to recognize them as refugees, but as the flow continued, the government created the National Commission on Refugees (CONARE) in order to control the growing Salvadorean population. Had the Honduran authorities been completely free to do what they wanted, very likely they would have forced all the Salvadoreans back across the border. But fortunately other factors had to be taken into consideration. Honduras, in the process of returning to a civilian government after years of military rule, was very concerned about its international image. Refoulement of thousands of Salvadoreans would certainly detract from the new democratic image that Honduras was seeking to create.

During this period, the UNHCR tried to work out some kind of arrangement with Honduras. This was complicated by the fact that Honduras had not signed either the 1951 Convention on Refugees or the 1967 Protocol. Nevertheless, it agreed to allow the UNHCR to operate within the country. In January 1981, the Honduran government and the UNHCR came to an agreement on the following four basic principles:

1. That Honduras would accept refugees seeking asylum;

2. That Honduras would respect the principle of non-refoulement;

3. That Salvadorean refugees would stay in zones designated to them by the Honduran authorities; and

4. That Salvadorean refugees would not be allowed to work.

Only two months after the agreement was reached, the Honduran military violated the first two points. In March 1981, when the Salvadorean National Guard entered the department of Cabañas, burning crops and houses and killing everyone it encountered, more than 7,000 peasants fled towards the Lempa River, which, like the Sumpul, forms the border between El Salvador and Honduras. As they tried to cross the river, they were shelled and shot at by both the Salvadorean and the Honduran military. Upon receiving word that a large number of Salvadoreans were being driven towards the Honduran border, humanitarian agency personnel, both Honduran and international, raced to the Lempa River. Because they arrived before the Hon- duran military had positioned itself along the banks of the river, they were able to help approximately 4,000 Salvadoreans reach the Honduran village of Los Hernández. Some 60 refugees were killed after their arrival in Honduras; the number that died in Salvadorean territory while trying to flee is unknown. In response to this situation, the UNHCR sent representatives to the border to negotiate minimum security conditions for the refugees with the civilian and military authorities. In early April, the UNHCR supervised the relocation of 3,000 refugees from Los Hernández to a camp situated below the town of La Virtud, near the Gualgüís River.

In November 1981, after another Salvadorean military operation in Cabañas, Honduran troops again tried to close the border to refugees. Nevertheless, many refugees continued to arrive during November and December, most of them having spent $15-30$ days hiding by day and moving by night. During this period, the pressure from the Honduran authorities to move the refugees out of the border region became very intense; both the Salvadorean and the Honduran military harassed and threatened the humanitarian agencies and the local Hondurans who were helping the refugees. In the period between November 1981 and April 1982, during the forced relocation of the Salvadorean refugees from the La Virtud/Guarita area to the camp of Mesa Grande near the town of San Marcos, 34 refugees and four Hondurans working with the refugees were killed, and a total of 45 Salvadoreans and Hondurans living in the border area disappeared. Many Honduran families were forced to flee to other parts of Honduras after receiving threats from Honduran soldiers for having helped the refugees.

The security of the Salvadorean refugees in Honduras has been of constant concern to the international community since that time. How can a refugee population be provided with protection when the most constant and serious threat to its security comes from the military of the host country? This concem became very concrete on August 29, 1985, when the Honduran military entered the Colomoncagua refugee camp in the province of Intibuca. This unprovoked 
military attack against a defenceless refugee population left two dead, two women raped, ten refugees captured and over thirty refugees wounded. This and other attacks on refugee camps are linked to the issue of relocation.

Since 1982, threats of forced relocation and rumours of forced repatriation have provoked one crisis after another. Over the last four years, four different plans to relocate the refugees to different sites within Honduras have been proposed successively. One after another, these plans have been abandoned in the face of strong domestic and international pressure against them. Within Honduras, some of the pressure against relocation came from sectors of Honduran society who supported the position of the refugees that any move would likely lead to deteriorated security, while others, such as certain sectors of the Honduran military, wanted to get rid of the refugees and favoured forced repatriation rather than relocation further into Honduran territory.

The most recent of the four relocation plans proposed the relocation of the refugees in Colomoncagua and San Antonio (Intibuca) to Mesa Grande. This would have concentrated over 20,000 refugees in a camp originally intended for 2,000 people. Given that repatriation did not seem to be realistic in the short term, this plan appeared to be acceptable to the Honduran military who felt that it could better control the refugees if they were all in one camp. ${ }^{1}$

The last several months have seen many important changes in Honduras that will likely influence the situation of the Salvadorean refugees. Two of the most important were the Honduran elections and the replacement of the Chief of Staff of the Honduran Armed Forces. Although the newly elected Liberal government has not announced an official position on the question of Salvadorean refugees, President Azcona has given a mixed message. He has stated that although his government will not move the refugees against their will, he is very worried that the Honduran government has little control over the camps. If these comments are indicative of the current thinking within the Honduran

1 Editor's Note: For a more detailed criticism of the relocation plans, see Martin Barber and Meyer Brownstone, "Relocating Refugees in Honduras", Refuge, 3, No. 2 (December 1983), pp. 12-15. government, it is likely that the refugees will be allowed to remain in their existing camps, but that the government will attempt to increase its involvement in the actual running of the camps.

This reading of the situation is backed by the fact that relocation, which was such a hot issue in the Honduran press in the last half of 1985, has not been mentioned at all since the beginning of 1986 . In February, the UNHCR confirmed that the most recent in a series of plans to relocate refugees from the camps of Colomoncagua and San Antonio had indeed been cancelled. Although there no longer appears to be any threat of relocation in the foreseeable future, the battle is not over. There are signs that the military presence around the camps has been increased and that administrative changes which would give the Honduran government more control over the programme are in the works.

Sources close to the situation feel that cancellation of the plans to move the refugees is directly related to recommendations made by Robert Gersony of the Refugee Bureau of the U.S. State Department. The U.S. Embassy in Honduras has always had a keen interest in seeing the refugee camps moved in order to clear the border area for military operations. Until recently, the Embassy has been the major force in favour of relocation. Robert Gersony visited Honduras in October and November 1985 to study the situation of the Salvadorean refugees and to make recommendations to the State Department with regard to its future handling of the situation. Apparently Gersony concluded that relocation of the camps at this time would be too complicated.

The refugees have always been firm that they would never move willingly, therefore it was clear that any attempt to relocate the camps would involve the use of violence by the military. It is interesting to note that the State Department re-evaluation of the situation took place in the wake of strong international outcry concerning the August 29 military attack on the camp of Colomoncagua and the ensuing criticism of Honduras regarding this incident in the Executive Committee meetings of the UNHCR. (The Honduran government was surprised and dismayed by the international reaction to this incident.) Gersony's principal concern was to determine what measures could be taken to ensure that the Honduran military would be satisfied that there were no guerrillas in the camps. Apparently he sees the solution in increased military control of the camps, in combination with increased administration of the refugee programme on the part of the Honduran government.

The second major event in recent months, the replacement of General Walter Lopez Reyes by General Humberto Regalado Hernández as head of the Honduran military, is interpreted by most analysts as a move to a more hardline position by the Honduran military. If this analysis is correct, it is likely to have serious consequences for the security of the refugees. In recent months, the trend has been towards more military presence and control of the camps. This is reflected in the frequency with which the military enters the camps and harasses the refugees. In January and February 1986, there were numerous incidents of this type.

Of particular concern is an incident which took place on the afternoon of February 16 when 20 soldiers entered Colomoncagua and set up three small-caliber machine guns inside camp territory beside the UNHCR house on the hilltop halfway between the sub-camps of Copinol and Callejones. The guns were set up only 30 meters above the chapel where Mass was being held. Half an hour later, the soldiers moved down to the soccer field in the Las Vegas sub-camp where they installed machine guns at the four corners of the field and settled in for the night. At 8:30 in the evening, they sent up a "light rocket" which illuminated the camps and then fell into the ravine behind the health centre where it set the hill on fire. Such incidents, whereby the military harasses and intimidates, are terrifying for a refugee population which has already suffered so much direct repression at the hands of the Honduran military. "Psychological warfare" of this nature has substantially increased the tension and fear in the camps.

As is frequently the case when the military enters the camps, there was no UNHCR protection officer present in either the camp or the town of Colomoncagua at the time of the February 16 incident. The refugees contend that the UNHCR protection presence is not adequate. They feel that the military deliberately chooses times when there is no UNHCR presence in order to enter the camps. For this reason, it is important that there always be at least one UNHCR protection officer present in each camp. This analysis of security needs is supported both by the agencies working in the refugee programme and by many international agencies and human rights 
ganizations which have been monitoring organization over the last five years (see the ICVA resolution on page 6).

agencies working in the refugee The arme under the co-ordination of the program have recently been informed by the UNHCR that the Honduran government is UNHCR interested in the "Mexican Model". very Mexico, the government is directly (In Msible for the administration of the respons programme through COMAR, the refugee pront refugee commission.) Over the governmear and a half, the Honduran last yearent has frequently complained in governmenturan press that it has no control the He camps. In November 1984, it over the issue of a permanent Honduran government presence in the camps. When questioned with regard to what type of people CONARE would place in the camps, Colonel Turcios replied that they were considering using retired military considennel. To date, no concrete action pes resulted from this, but now that has ration is no longer on the agenda, it relocars that the Honduran government's interest in this proposal has been revived.

There are also other indications that the Honduran government is making a move to assert control over the situation. Three of the most recent indications are:

1. In mid-February, two articles in the Honduran press announced that MSF Médecins Sans Frontières, the French medical agency whose international volunteers run the health programme in the camps) would be asked to leave the programme by May of this year and would be replaced by Honduran doctors. The incident that provoked the story, concerning a Honduran doctor who blamed MSF for losing his job, was blown out of proportion by the Ministry of Health which used the occasion to lobby against the presence of MSF in the refugee programme. Lengthy negotiations were necessary to ensure the continued participation of international medical personnel in the programme. (The presence of international agency personnel in the camps has always been extremely important in terms of the security of the refugees.)

2. On February 19, the immigration officials in San Marcos, near the camp of Mesa Grande, informed the UNHCR that no new male refugees between the ages of 18 and 50 would be allowed to enter the camps. Several men in this age bracket had just arrived and Honduran immigration officials were threatening to deport them. These new refugees were kept in the UNHCR house in San Marcos until the UNHCR was able to negotiate their entrance into Mesa Grande. In the end the UNHCR also was able to have the new restriction rescinded. The successful resolution of this particular crisis through the immediate intervention of the UNHCR only serves to underline the importance of its presence in the camps at all times.

3. It appears that all requests for permission to enter the camps, both for visitors as well as for new staff persons, must now be addressed directly to Colonel Turcios. Previously, requests were made to Colonel Turcios via the UNHCR.

Of primary concern in this increasingly complex situation is how to guarantee security when the very authorities that have been responsible for threats to the security of the refugees are beginning to insist on more control over the camps. Although the Honduran government has a sovereign right to determine what happens within its territory, this does not relieve it of its international legal obligations to respect the human rights of the refugees within its borders. Since there are no international mechanisms which guarantee that these legal obligations are respected, the international community has a moral obligation to defend a refugee population whose human rights are being threatened.

Experience over the last few years has shown that international pressure with regard to this issue has been extremely effective. Although it appears that all plans to relocate Salvadorean refugees from Colomoncagua and San Antonio have been officially cancelled, the position of the refugees continues to be extremely precarious. In the context of escalating intimidation and harassment of the refugees by the Honduran military, the continued role of the UNHCR in the co-ordination of the programme, and the presence of sufficient numbers of qualified UNHCR protection officers and international agency staff in the camps continue to be essential for the security of the Salvadorean refugees.

Sandra Pentland is an associate of the Jesuit Centre for Social Justice. Denis Racicot is an immigration lawyer. Both work with the Comité de travail sur les réfugiés (COTRAC) in Montreal.

\section{From \\ Howard Adelman: Next Year on Sabbatical}

I wish to thank all those graduate students at York University who have helped produce this year's Refuge. Alex Zisman and Tanya Basok, in fact, assumed full editorial responsibility for this excellent current issue on Central American refugees. Without the help of Leslie Rider, my research assistant and the Managing Editor, we would all be lost.

I also wish to thank our loyal readers whose continuing subscriptions and extra support have enabled us to continue to publish Refuge. I hope we have made a contribution to the understanding of the problem of refugees and the policy issues with which we all must grapple.

Next year I am away on sabbatical. In 1979 , at the beginning of my last sabbatical, I got caught up in the refugee issues of the Boat People and Operation Lifeline. Since then I have sustained that involvement and helped develop the refugee research unit at York University and the publication Refuge. It is time to resume my concentration on my work in philosophy while I write the results of my research on refugees.

Michacl Lanphier, Professor of Sociology at York University, succeeds me as Director of the Refugee Documentation Project and Editor of Refuge. Michael has a distinguished record as both a scholar dealing with refugee issues and as a committed individual. Alex Zisman will assist Michael by serving as Feature Editor of Refuge and Noreen Nimmons will take over as Managing Editor.

I am sure you all join me in wishing them and all the others associated with the Refugee Documentation Project at York University the best in their future work.

Howard Adelman 